\title{
EVALUASI TINGKAT KUALITAS LAYANAN INDUSTRI MODA TRANSPORTASI PUBLIK DENGAN INTEGRASI PENDEKATAN SERVQUAL DAN IPA DIAGRAM
}

\author{
${ }^{1}$ Syamsul Bahri, ${ }^{2}$ Armin Darmawan \\ 1,2 Departemen Teknik Industri, Fakultas Teknik, Universitas Hasanuddin \\ e-mail: darmawanarmin@gmail.com
}

\begin{abstract}
Abstrak
Perhatian publik terhadap kebutuhan layanan transportasi menjadi perhatian penting utamanya di Negara-negara berkembang. Kajian ini berfokus pada analisis tingkat layanan transportasi public, dan tingkat ekspektasi terhadap suatu layanan transportasi publik. Metode kajian menggunakan survey terhadap responden yang menggunakan layanan transportasi publik dengan instrumen kuesioner yang berbasis pada SERVQUAL. SERVQUAL merupakan metode yang handal dalam melakukan pemetaan tingkat kepuasaan pelanggan dengan lima dimensi; reliability, tangible, assurance, empathy, responsiveness. Hasil menunjukkan pemetaan 22 atribut bernilai negative yang berarti terdapat masalah ketidakpuasan pada hampir seluruh layanan. Berdasarkan pendekatan diagram Importance-Performance Analysis menunjukkan dari 22 atribut terdapat 6 atribut (4 atribut pada dimensi Tangible, satu atribut pada dimensi Assurance dan satu atribut pada dimensi Empathy) yang dominan mempengaruhi tingkat kepuasan pelanggan artinya menurut pelanggan bahwa enam atribut tersebut penting dan disisi lain kinerja layanannya rendah. Sehingga diperlukan langkah-langkah improvement untuk kembali meningkatkan tingkat kualitas layanan.
\end{abstract}

Kata kunci : SERVQUAL, Transportasi, Diagram IPA

\section{PENDAHULUAN}

Salah satu layanan publik yang menjadi perhatian utama para pemangku kepentingan khususnya penyedia jasa layanan beberapa dekade terakhir adalah terkait dengan layanan moda transportasi publik. Hal ini dikarenakan bahwa layanan transportasi baik itu darat, laut maupun udara merupakan salah satu kebutuhan penting manusia. Kebutuhan ini membantu memobilisasi perpindahan dari desa ke kota dan sebaliknya, antar kota, dalam kota, bahkan antar negara. Pertumbuhan dan perkembangan kebutuhan layanan masyarakat menuntut para penyedia jasa layanan tidak hanya terpaku pada aspek primer mobilisasi tapi juga aspek layanan lainnya yang dapat menyediakan fitur-fitur layanan yang dapat memberi kepuasan konsumen.

Kebutuhan layanan tersebut umumnya berfokus pada ketersediaan moda transportasi yang ramah dan layanan yang mampu memenuhi kepuasan pengguna. Salah satu respon dari perhatian ini bahwa di beberapa negara telah melakukan transformasi layanan moda transportasi publik mereka dari traditional transportation system kepada yang namanya flexible transit system. Suatu adopsi penerapan teknologi yang mengintegrasikan beberapa perangkat teknologi pendukung seperti system penjadwalan dan pemesanan tiket otomatis, penggunaan GPS sebagai alat pandu telusur, serta akses informasi yang cepat dan akurat. Adopsi teknologi ini, selain meningkatkan strategi operasional layanan juga berkontribusi pada fleksibilitas dan efektifitas layanan (Saeed \& Kurauchi, 2015). Pengembangan transportasi publik diharapkan dapat membuat masyarakat lebih mudah dalam melakukan perjalanan dengan layanan, system transport, kualitas dan kinerja operasional yang bagus (Putra \& Sitanggang, 2016).

Layanan transportasi publik darat baik pada angkutan antar kota maupun dalam area perkotaan membutuhkan inovasi-inovasi dalam rangka memenuhi dan memuaskan kebutuhan pengguna. Dalam kaitannya itu, terdapat tiga dimensi yang menjadi pertimbangan yaitu dari sisi industri sebagai produsen moda dan juga dari sisi pelanggan. Dari sisi industri umumnya menekankan pada kinerja dasar dari moda transportasi seperti kinerja mesin, fitur-fitur standar, layanan perawatan dan estetika. Sedang dari sisi konsumen menekankan pada sejauh mana moda transportasi itu dapat bermanfaat secara efektif dan nyaman. Selain kedua dimensi tersebut, dimensi terakhir yaitu kualitas layanan penyedia jasa transportasi publik. 
Dimensi konsumen dan penyedia jasa layanan merupakan hubungan yang bersifat langsung. Kualitas layanan secara langsung dirasakan oleh kosumen sejak awal layanan hingga akhir layanan. Hal ini berakibat pada saling ketergatungan antara dua dimensi tersebut. Konsumen membutuhkan jasa layanan transportasi sebagai moda untuk berpindah dari satu kota ke kota lainnnya maupun dalam kota. Sedang disisi lain jasa layanan transportasi membutuhkan konsumen sebagai timbal balik pencapaian keuntungan dari jasa yang mereka sediakan. Sehingga suatu jasa layanan khususnya layanan transportasi sangat tergantung dengan tingkat hubungan terhadap konsumen harus memahami kebutuhan spesifik konsumen (Parasuraman, Berry, \& Zeithaml, 1991).

Dengan melakukan transformasi layanan ke model yang terintegrasi tentunya merupakan jalan peningkatan kualitas layanan yang dapat memenuhi ekspetasi pelanggan. Proses transformasi ini membutuhkan kajian yang komprehensif dari hulu hingga hilir yang melibatkan semua pemangku kepentingan. Sehingga kebutuhan akan transportasi publik yang efektif dan nyaman dapat terpenuhi.

Menyadari peran penting konsumen maka sebagai langkah awal kajian perlu melakukan pemetaan tingkat kepuasan dan tingkat kualitas layanan moda transportasi publik. Untuk itu membutuhkan kajian eksisting melalui aspek dua dimensi yaitu dari aspek konsumen pengguna layanan dan penyedia jasa layanan. Untuk menganalisis tingkat kualitas layanan suatu moda transportasi publik membutuhkan penilaian dan pengukuran pengguna layanan dan pengukuran tingkat kepuasan pelanggan.

Metode yang digunakan dalam memetakan tingkat kepuasan konsumen dan tingkat kualitas layanan moda transportasi yaitu SERVQUAL. SERVQUAL telah banyak diterapkan dalam kajian layanan di berbagai bidang. Khusus pada bidang transportasi telah dilakukan banyak kajian terakhir diantaranya Aydemir \& Gern (2011), Erdil \& Yildiz (2011), Pabedinskaite \& Akstinaite (2014), Putra \& Sitanggang (2016), Barabino \& Deiana (2013), Saeed \& Kurauchi (2015), dan logistic dengan lintas layanan transportasi oleh Limbourg, Giang, \& Cools (2016). SERVQUAL dirancang untuk mengukur kualitas jasa yang dirasakan oleh konsumen. SERVQUAL terdiri dari lima dimensi kualitas pelayanan yaitu kehandalan (reliability), jaminan (assurance), fisik (tangible), empati (empathy), dan daya tanggap (responsiveness). Metode SERVQUAL ini bermanfaat dalam melakukan identifikasi dan analisis gap terkait dengan ekspektasi/harapan konsumen dengan persepsi yang dirasakan konsumen atas kualitas layanan.

Untuk pemetaan secara spesifik hasil output dari SERVQUAL, maka dilakukan analisis tingkat kinerja dan kepentingan dari suatu layanan melalui pemetaan diagram Importance-Performance Analysis (IPA). Hasil analisis ini memberi gambaran terkait atribut apa saja dari persepsi konsumen penting dan memerlukan peningkatan kualitas. Hal ini membantu penyedia jasa layanan dalam menentukan prioritas atribut yang memerlukan peningkatan kualitas segera. Selain itu, kelanjutan pengembangan metodologis dilakukan dengan mengadopsi pendekatan AHP (Analytical Hierarchy Process) yang dikembangkan Saaty sebagai salah satu metode yang digunakan dalam menentukan prioritas bila terdapat beberapa alternative atribut yang memerlukan peningkatan kualitas.

Kajian evaluasi tingkat kualitas layanan pada moda transportasi publik di daerah ini khususnya wilayah Indonesia bagian timur masih sangat terbatas (Goh, 2016). Berdasarkan latar belakang diatas, kajian secara empiris dilakukan pada salah satu moda transportasi darat antar kota pada tujuan destinasi wisata dunia di Sulawesi Selatan. Kajian ini dilakukan untuk menjawab bagaimana tingkat layanan yang dirasakan oleh konsumen dari sisi ekspektasi dan persepsi dalam layanan moda transportasi publik.

Tujuan penelitian ini menekankan pada pemetaan kondisi terkini yang terkait dengan dimensi yang dipertimbangkan yaitu dimensi persepsi konsumen yang menjadi titik poin dalam mengembangkan kualitas layanan yang diurai dalam tiga tujuan utama yaitu memetakan tingkat kepuasan konsumen terhadap kinerja layanan penggunaan moda layanan transportasi public, 
mengevaluasi tingkat kualitas layanan penyedia jasa moda layanan transportasi publik, dan mengembangkan rekomendasi untuk peningkatan kualitas layanan transportasi publik.

\section{METODE PENELITIAN}

Penelitian ini dilakukan pada salah satu industri moda layanan transportasi antar kota (Makassar - Toraja) di Sulawesi Selatan pada tahun 2017. Pengumpulan data dilakukan dengan melakukan identifikasi atribut penelitian yang mencerminkan tingkat ekspektasi dan persepsi konsumen. Atribut penelitian didasarkan pada model SERVQUAL dengan lima dimensi. Model ini dikembangkan dalam kuesioner sebagai instrument kajian yang akan dilakukan analisis. Kuesioner ini akan disebarkan ke responden yang menggunakan layanan moda transportasi publik. Penyusunan kuesioner dilakukan dalam bentuk pertanyaan tertutup. Pertanyaan tertutup artinya pertanyaan yang membawa responden ke jawaban yang alternatifnya sudah ditetapkan sebelumnya. Penilaian yang dilakukan responden pada setiap atribut dalam kuesioner menggunakan skala likert 1 hingga 5. Untuk tingkat persepsi penialaian atribut yaitu: 1. Sangat Tidak Memuaskan, 2. Tidak Memuaskan, 3. Netral, 4. Memuaskan, 5. Sangat Memuaskan. Tingkat ekspektasi yaitu: 1. Sangat Tidak Penting, 2. Tidak Penting, 3. Netral, 4. Penting, 5. Sangat Penting.

\section{A. Atribut Penelitian}

Atribut penelitian yang disajikan dalam kuesioner merupakan penjabaran dari 5 dimensi SERVQUAL. Adapun atribut untuk masing-masing dimensi tersebut dijabarkan sebagai berikut:

Tabel 1. Atribut Kuesioner

\begin{tabular}{cc}
\hline KODE & DIMENSI \& ATRIBUT \\
\hline A & Bukti Fisik (Tangibles) \\
A1 & Kebersihan ruang tunggu perwakilan dan di dalam bus \\
A2 & Kebersihan toilet dan kelengkapannya \\
A3 & Karyawan selalu berpenampilan rapi \\
A4 & Fasilitas bus dan perwakilan yang modern \\
A5 & Tampilan interior bus dan perwakilan menarik \\
B & Reliabilitas (Reliability) \\
B1 & Keberangkatan bus tepat waktu \\
B2 & Fasilitas bus dan perwakilan sesuai dengan yang ditawarkan \\
B3 & Sistem pencatat tiket akurat dan bebas kesalahan \\
B4 & Penanganan masalah pelanggan yang tenang dan akurat \\
C & Daya Tanggap (Responsivenes) \\
C1 & Kemudahan dan kejelasan informasi waktu keberangkatan dan \\
C2 & jenis bus \\
C3 & Karyawan selalu bersedia membantu dan menanggapi pelanggan \\
C4 & dengan cepat \\
D & Pelayanan maksimal terhadap pelanggan \\
D1 & Jaminan (Assurance) \\
D2 & Rasa aman sewaktu dalam perjalanan \\
D3 & Kenyamanan di ruang tunggu dan dalam perjalanan \\
D4 & Karyawan yang terpercaya dan berwawasan luas \\
E & Karyawan (Pengemudi) yang professional \\
E1 & Empati (Empathy) \\
E2 & Harga tiket terjangkau bagi seluruh segmentasi pelanggan \\
E3 & Lokasi perwakilan mudah dijangkau (strategis) \\
& Karyawan tidak memandang status sosial dalam melayani \\
\hline
\end{tabular}


E4 Karyawan sungguh-sungguh memperhatikan kebutuhan setiap pelanggan

E5 Karyawan selalu bersikap sopan dan ramah terhadap para pelanggan

Penentuan jumlah responden didasarkan pada populasi konsumen yang menggunakan suatu layanan moda transportasi publik terkait. Jumlah sampel diambil sebesar 400 responden yang diambil secara langsung berdasarkan teknik random sampling berdasarkan zona pergerakan penumpang (Miranda, Ponto, \& Olmos, 2014).

\section{B. Analisis Data Deskriptif}

Data survey yang diperoleh dalam bentuk kualitative dikumpulkan dan dilakukan analisis statistik deskriptif mengenai karakteristik responden. Data kualitatif ditransformasikan ke dalam bentuk kuantitative yang diproses dengan teknik analisis statistik yaitu uji validitas dan uji reliabilitas.

\section{Analisis GAP}

Analisis GAP mengidentifikasi secara detail tingkat kesenjangan untuk tiap indikator pada dimensi SERVQUAL. Analisis ini membantu dalam membangun pemahaman seberapa besar tingkat kesenjangan antara persepsi dan harapan dari tiap responden yang mengonsumsi jasa layanan. Tingkat kesenjangan yang teridentifikasi disusun secara berurutan dari tingkat kesenjangan tertinggi hingga terendah.

\section{Importance-Performance Analysis}

Pemetaan tingkat kesenjangan dalam bentuk kuadran Importance-Performance Analysis memberikan arahan pada pengambil keputusan. Pemetaan ini disusun dalam bentuk 4 kuadran berdasarkan hasil responden dari sisi tingkat kepentingan atribut dan kinerja layanan yaitu: Kuadran Pertama menunjukkan Tingkat Kinerja Rendah namun berdasarkan preferensi responden atribut tersebut merupakan hal yang penting, Kuadran Kedua menunjukkan Tingkat Kinerja Tinggi dan Atribut Penting, Kuadran Ketiga menunjukkan Tingkat Kinerja Tingga namun atribut yang berada pada kuadran ketiga tidak begitu penting berdasarkan preferensi konsumen, dan yang terakhir kuadran keempat menjelaskan tingkat kinerja rendah dan menurut konsumen atribut tersebut tidak begitu penting.

\section{HASIL DAN PEMBAHASAN}

Pada bagian kajian ini menunjukkan beberapa hasil yang berdasarkan pada hasil sebaran angket pada responden. Deskripsi ringkas terhadap karakteristik responden dapat dilihat pada tabel 2, dan dengan analysis gap yang berdasarkan pada SERVQUAL pada tabel 2. 
Tabel 2. Karakteristik Responden

\begin{tabular}{|c|c|c|}
\hline $\begin{array}{l}\text { Atribut Social dan } \\
\text { Demografi }\end{array}$ & Sub Atribut & Persentase \\
\hline \multirow[t]{2}{*}{ Jenis Kelamin } & Laki-laki & $42.00 \%$ \\
\hline & Perempuan & $58.00 \%$ \\
\hline \multirow[t]{5}{*}{ Usia } & $<20$ tahun & $20.00 \%$ \\
\hline & $21-30$ tahun & $39.00 \%$ \\
\hline & $31-40$ tahun & $22.00 \%$ \\
\hline & $41-50$ tahun & $15.00 \%$ \\
\hline & $>50$ tahun & $4.00 \%$ \\
\hline \multirow[t]{4}{*}{ Pedidikan } & $<=$ SMA & $66.00 \%$ \\
\hline & D3 & $6.75 \%$ \\
\hline & S1 & $27.00 \%$ \\
\hline & $\mathrm{S} 2>$ & $0.25 \%$ \\
\hline \multirow[t]{7}{*}{ Pekerjaan } & Pelajar & $36.00 \%$ \\
\hline & Mahasiswa & $6.00 \%$ \\
\hline & PNS/TNI/Polri & $18.00 \%$ \\
\hline & Wiraswasta & $11.00 \%$ \\
\hline & Pegawai & $29.00 \%$ \\
\hline & Swasta & \\
\hline & $\begin{array}{l}\text { Ibu Rumah } \\
\text { Tangga }\end{array}$ & \\
\hline
\end{tabular}

\section{A. Uji Validitas}

Uji validitas untuk menunjukkan sejauh mana alat pengukur ini dapat mengukur apa yang diukur atau kemampuan pengukuran senyatanya. Pengertian valid adalah bahwa kuisioner efektif dapat digunakan sebagai alat pengumpul data untuk menggali masalah yang dijadikan obyek penelitian. Efektifitas didasarkan pada asumsi bahwa kuisioner penelitian mudah dimengerti dan mudah dijawab oleh para responden penelitian.

Pengukuran validitas instrumen penelitian dilakukan dengan menggunakan rumus koefisien korelasi Pearson Product Moment. Kriterianya adalah jika $r$ hitung lebih besar dari $r$ tabel berarti valid, dan sebaliknya jika $r$ hitung lebih kecil dari $r$ tabel berarti tidak valid. Pengujian ini dilakukan dengan menggunakan perangkat lunak SPPS 20 for windows. Pengujian ini dilakukan dengan mengkorelasikan butir pernyataan dengan nilai skor total dari 100 responden sebagai pilot sampel dengan taraf signifikan 5\% atau taraf kepercayaan $95 \%$.

Tabel 3. Hasil Uji Validitas

\begin{tabular}{ccccccc}
\hline Kode & $\begin{array}{c}\text { r- } \\
\text { hitung }\end{array}$ & r-tabel & Keterangan & $\begin{array}{c}\text { r- } \\
\text { hitung }\end{array}$ & r-tabel & Keterangan \\
\hline A1 & 0.356 & 0.196 & Valid & 0.459 & 0.196 & Valid \\
A2 & 0.250 & 0.196 & Valid & 0.401 & 0.196 & Valid \\
A3 & 0.385 & 0.196 & Valid & 0.500 & 0.196 & Valid \\
A4 & 0.499 & 0.196 & Valid & 0.518 & 0.196 & Valid \\
A5 & 0.358 & 0.196 & Valid & 0.551 & 0.196 & Valid \\
B1 & 0.581 & 0.196 & Valid & 0.545 & 0.196 & Valid \\
B2 & 0.487 & 0.196 & Valid & 0.563 & 0.196 & Valid \\
B3 & 0.495 & 0.196 & Valid & 0.523 & 0.196 & Valid \\
B4 & 0.584 & 0.196 & Valid & 0.603 & 0.196 & Valid \\
C1 & 0.602 & 0.196 & Valid & 0.419 & 0.196 & Valid \\
C2 & 0.539 & 0.196 & Valid & 0.551 & 0.196 & Valid \\
\hline
\end{tabular}




\begin{tabular}{lccllll}
\hline C3 & 0.384 & 0.196 & Valid & 0.386 & 0.196 & Valid \\
C4 & 0.377 & 0.196 & Valid & 0.520 & 0.196 & Valid \\
D1 & 0.679 & 0.196 & Valid & 0.452 & 0.196 & Valid \\
D2 & 0.340 & 0.196 & Valid & 0.531 & 0.196 & Valid \\
D3 & 0.313 & 0.196 & Valid & 0.519 & 0.196 & Valid \\
D4 & 0.580 & 0.196 & Valid & 0.551 & 0.196 & Valid \\
E1 & 0.607 & 0.196 & Valid & 0.504 & 0.196 & Valid \\
E2 & 0.708 & 0.196 & Valid & 0.561 & 0.196 & Valid \\
E3 & 0.710 & 0.196 & Valid & 0.655 & 0.196 & Valid \\
E4 & 0.781 & 0.196 & Valid & 0.574 & 0.196 & Valid \\
E5 & 0.69 & 0.196 & Valid & 0.741 & 0.196 & Valid \\
\hline
\end{tabular}

Hasil uji validitas dengan mengacu pada hasil formulasi koefisien Pearson Correlation Product Momen seperti yang tersaji pada tabel 3 menunjukkan bahwa hasil koefisien korelasi seluruh kriteria lebih besar dari angka penguji (r-tabel : 0.195, n 100).

Hal tersebut mengindikasikan bahwa indikator-indikator penelitian dapat digunakan sebagai instrument ukur dalam pengumpulan data yang efektif untuk memetakan dan mengidenifikasi masalah yang dijadikan obyek penelitian, dan selanjutnya dapat diolah untuk mengukur dimensi-dimensi kajian dan indikator-indikator penelitian pada masingmasing dimensi kajian.

\section{B. Uji Reliabilitas}

Pengujian reliabilitas instrument alat ukur dilakukan untuk mengetahui tingkat keandalan/konsistensi instrumen yang digunakan dalam mengumpulkan data.

Pengertian andal/reliabel adalah bilamana alat ukur yang digunakan dapat diandalkan dan konsisten, artinya tidak terdapat perbedaan persepsi responden terhadap suatu item instrumen. Karena dalam situasi yang berbeda bias saja instrument penelitian menimbulkan persepsi yang jauh berbeda. Untuk itu dalam menguji tingkat konsistensi ini dilakukan uji reliabilitas dengan berdasarkan kriteria jika $r$ hitung $<r$ tabel berarti tidak reliabel dan jika $r$ hitung $>r$ tabel berarti reliable.

Selain itu, tingkat reliailitas didasarkan pada nilai cronbach's alpha dimana jika nilai alpha $>0,7$ artinya reliabilitas mencukupi (sufficient reliability) sementara jika alpha $>0,80$ ini mensugestikan seluruh item reliabel dan seluruh tes secara konsisten secara internal karena memiliki reliabilitas yang kuat. Atau, ada pula yang memaknakannya sebagai berikut:

a. Jika alpha $>0,90$ maka reliabilitas sempurna

b. Jika alpha antara $0,70-0,90$ maka reliabilitas tinggi

c. Jika alpha antara $0,50-0,70$ maka reliabilitas moderat

d. Jika alpha $<0,50$ maka reliabilitas rendah.

Jika alpha rendah, kemungkinan satu atau beberapa item tidak reliable, untuk itu dilakukan identifikasi dengan prosedur analisis per item. Item Analysis adalah kelanjutan dari tes Aplha sebelumnya guna melihat item-item tertentu yang tidak reliabel. Melalui item analisis ini maka satu atau beberapa item yang tidak reliabel dapat dibuang sehingga alpha dapat lebih tinggi lagi nilainya.

Reliabilitas item diuji dengan melihat koefisien alpha dengan melakukan Reliability Analysis dengan SPSS ver. 20 for Windows. Dari hasil nilai Alpha-Cronbach untuk reliabilitas keseluruhan item dalam satu variabel. Hasil uji realibilitas untuk data ekspektasi dan persepsi pengguna dapat dilihat pada tabel 4.

Hasil uji realibilitas untuk data ekspektasi dan persepsi pengguna dapat dilihat pada tabel 4. Hasil pengujian reabilitas tersebut (tabel 4), keseluruhannya bermakna bahwa indikatorindikator penelitian yang dijadikan kuisioner penelitian dan dipergunakan sebagai alat pengumpul data primer ternyata dapat diandalkan untuk mengukur masing-masing dimensi yang dioperasionalkan guna mengungkap masalah-masalah yang dijadikan obyek penelitian. 
Kriteria keandalan (reliable) instrumen pengumpul data primer ini penting sekali karena para pihak yang menjadi sampel penelitian memiliki karakteristik dan daya persepsi yang berbeda.

Tabel 4. Hasil Uji Reliabilitas

\begin{tabular}{|c|c|c|c|}
\hline \multirow{2}{*}{ Kode } & \multicolumn{3}{|c|}{ Nilaii Cronbach's Alpha } \\
\hline & Importance & Performance & Uji Reliabilitas \\
\hline A1 & 0.858 & 0.872 & Reliable \\
\hline A2 & 0.860 & 0.875 & Reliable \\
\hline A3 & 0.860 & 0.871 & Reliable \\
\hline A4 & 0.852 & 0.870 & Reliable \\
\hline A5 & 0.857 & 0.869 & Reliable \\
\hline B1 & 0.850 & 0.869 & Reliable \\
\hline B2 & 0.853 & 0.869 & Reliable \\
\hline B3 & 0.852 & 0.870 & Reliable \\
\hline B4 & 0.849 & 0.867 & Reliable \\
\hline $\mathrm{C} 1$ & 0.849 & 0.873 & Reliable \\
\hline $\mathrm{C} 2$ & 0.850 & 0.869 & Reliable \\
\hline $\mathrm{C} 3$ & 0.857 & 0.876 & Reliable \\
\hline $\mathrm{C} 4$ & 0.857 & 0.870 & Reliable \\
\hline D1 & 0.847 & 0.872 & Reliable \\
\hline D2 & 0.857 & 0.870 & Reliable \\
\hline D3 & 0.864 & 0.870 & Reliable \\
\hline D4 & 0.850 & 0.869 & Reliable \\
\hline E1 & 0.848 & 0.871 & Reliable \\
\hline E2 & 0.843 & 0.869 & Reliable \\
\hline E3 & 0.843 & 0.865 & Reliable \\
\hline E4 & 0.839 & 0.868 & Reliable \\
\hline E5 & 0.844 & 0.862 & Reliable \\
\hline
\end{tabular}

Berdasarkan hasil pengujian validitas instrumen dan reabilitas alat ukur diketahui bahwa data yang diperoleh dari para responden yang menjadi sampel penelitian dapat dinyatakan valid dan reliable, selanjutnya data tersebut diolah untuk melakukan pengukuran kepuasan pelanggan.

\section{Perhitungan Nilai SERVQUAL}

Hasil pengolahan data menunjukkan pemetaan berdasarkan lima dimensi SERVQUAL dengan nilai ekspektasi dan persepsi dari responden dapat dilihat pada penjelasan berikut. 
Tabel 5. Gap Score Lima Dimensi SERVQUAL

\begin{tabular}{|c|c|c|c|c|}
\hline $\begin{array}{l}\text { Ko } \\
\text { de }\end{array}$ & Dimensi \& Atribut & $\begin{array}{l}\text { Importan } \\
\text { ce Score }\end{array}$ & $\begin{array}{l}\text { Performa } \\
\text { nce Score }\end{array}$ & GAP \\
\hline $\mathbf{A}$ & \multicolumn{4}{|c|}{ Bukti Fisik (Tangibles) } \\
\hline A1 & $\begin{array}{l}\text { Kebersihan ruang tunggu perwakilan dan di dalam } \\
\text { bus }\end{array}$ & 4.61 & 3.30 & -1.30 \\
\hline A2 & Kebersihan toilet dan kelengkapannya & 4.75 & 2.85 & -1.89 \\
\hline A3 & Karyawan selalu berpenampilan rapi & 3.60 & 3.14 & -0.46 \\
\hline A4 & Fasilitas bus dan perwakilan yang modern & 4.57 & 3.36 & -1.21 \\
\hline A5 & Tampilan interior bus dan perwakilan menarik & 4.65 & 3.39 & -1.25 \\
\hline B & \multicolumn{4}{|l|}{ Reliabilitas (Reliability) } \\
\hline B1 & \multirow{2}{*}{$\begin{array}{l}\text { Keberangkatan bus tepat waktu } \\
\text { Fasilitas bus dan perwakilan sesuai dengan yang } \\
\text { ditawarkan }\end{array}$} & 4.82 & 4.16 & -0.67 \\
\hline B2 & & 3.74 & 3.45 & -0.28 \\
\hline B3 & \multirow{2}{*}{$\begin{array}{c}\text { Sistem pencatat tiket akurat dan bebas kesalahan } \\
\text { Penanganan masalah pelanggan yang tenang dan } \\
\text { akurat }\end{array}$} & 4.69 & 4.05 & -0.64 \\
\hline B4 & & 4.33 & 3.56 & -0.77 \\
\hline $\mathbf{C}$ & \multicolumn{4}{|c|}{ Daya Tanggap (Responsivenes) } \\
\hline $\mathrm{C} 1$ & $\begin{array}{l}\text { Kemudahan dan kejelasan informasi waktu } \\
\text { keberangkatan dan jenis bus }\end{array}$ & 4.81 & 3.95 & -0.86 \\
\hline $\mathrm{C} 2$ & Semua transaksi dilayani dengan tepat dan cepat & 4.58 & 3.82 & -0.75 \\
\hline $\mathrm{C} 3$ & $\begin{array}{l}\text { Karyawan selalu bersedia membantu dan } \\
\text { menanggapi pelanggan dengan cepat }\end{array}$ & 3.56 & 3.41 & -0.15 \\
\hline $\mathrm{C} 4$ & Pelayanan maksimal terhadap pelanggan & 4.51 & 3.47 & -1.04 \\
\hline D & \multicolumn{4}{|l|}{ Jaminan (Assurance) } \\
\hline D1 & Rasa aman sewaktu dalam perjalanan & 4.82 & 3.96 & -0.86 \\
\hline D2 & Kenyamanan di ruang tunggu dan dalam perjalanan & 4.58 & 3.3 & -1.24 \\
\hline D3 & Karyawan yang terpercaya dan berwawasan luas & 4.00 & 3.2 & -0.77 \\
\hline D4 & Karyawan (Pengemudi) yang professional & 4.75 & 3.89 & -0.86 \\
\hline $\mathbf{E}$ & \multicolumn{4}{|l|}{ Empati (Empathy) } \\
\hline E1 & $\begin{array}{c}\text { Harga tiket terjangkau bagi seluruh segmentasi } \\
\text { pelanggan }\end{array}$ & 4.57 & 3.37 & -1.20 \\
\hline E2 & Lokasi perwakilan mudah dijangkau (strategis) & 4.43 & 3.66 & -0.77 \\
\hline E3 & $\begin{array}{c}\text { Karyawan tidak memandang status sosial dalam } \\
\text { melayani pelanggan }\end{array}$ & 4.37 & 3.63 & -0.75 \\
\hline E4 & $\begin{array}{c}\text { Karyawan sungguh-sungguh memperhatikan } \\
\text { kebutuhan setiap pelanggan }\end{array}$ & 4.30 & 3.40 & -0.90 \\
\hline E5 & $\begin{array}{l}\text { Karyawan selalu bersikap sopan dan ramah terhadap } \\
\text { para pelanggan }\end{array}$ & 4.36 & 3.49 & -0.87 \\
\hline
\end{tabular}

Berdasarkan tabel 5.1 diperoleh hasil penilaian mengenai kualitas layanan jasa transportasi melalui 22 kriteria penilaian oleh responden (pengguna layanan transortasi). Dari perhitungan nilai servqual didapatkan bahwa secara keseluruhan atribut bernilai negatif, ini menunjukkan bahwa pelanggan secara umum tidak puas terhadap kualitas layanan tersebut. Salah satu atribut yang paling mempengaruhi kepuasan pengguna jasa transportasi yaitu pada kebersihan toilet dan kelengkpannya yang dirasa sangat kurang oleh pengguna sedangkan ekspektasi pengguna terhadap keersihan toilet dan kelengkapannya sangat besar sehingga terjadi gap yang sangat tinggi. Untuk itu, perusahaan sebaiknya harus memerhatikan kualitas layanan terutama pada dimensi tangible yang dimana beberapa hal yang terkait dengan tampilan fisik seperti kebersihan ruang tunggu, kebersihan toilet, fasilitas yang ditawarkan dalam bus harus dilakukan peningkatan kualitas. 
Selain dimensi tangible, dimensi empathy perlu dipertimbangkan untuk dilakukan peningkatan komitmen kinerja utamanya pada kesesuaian harga tiket dengan kemampuan pelanggan yang tergambar dari karakteristik responden yang didominasi oleh pelajar dan mahasiswa.

Hasil gap analysis kemudian dilakukan pemetaan dengan menggunakan pendekatan diagram Importance-Performance Analysis. Diagram IPA digunakan sebagai penentuan prioritas perbaikan yakni dengan menggabungkan pengukuran faktir tingkat kepentingan dan tingkat kepuasan dalam grafik dua dimensi yang memudahkan penjelasan data dan mendapatkan usulan praktis. Diagram IPA di bawah ini adalah diagram IPA pada lima variable dalam servqual. Diagram ini menganalisis dimensi yang kinerjanya kurang memuaskan.
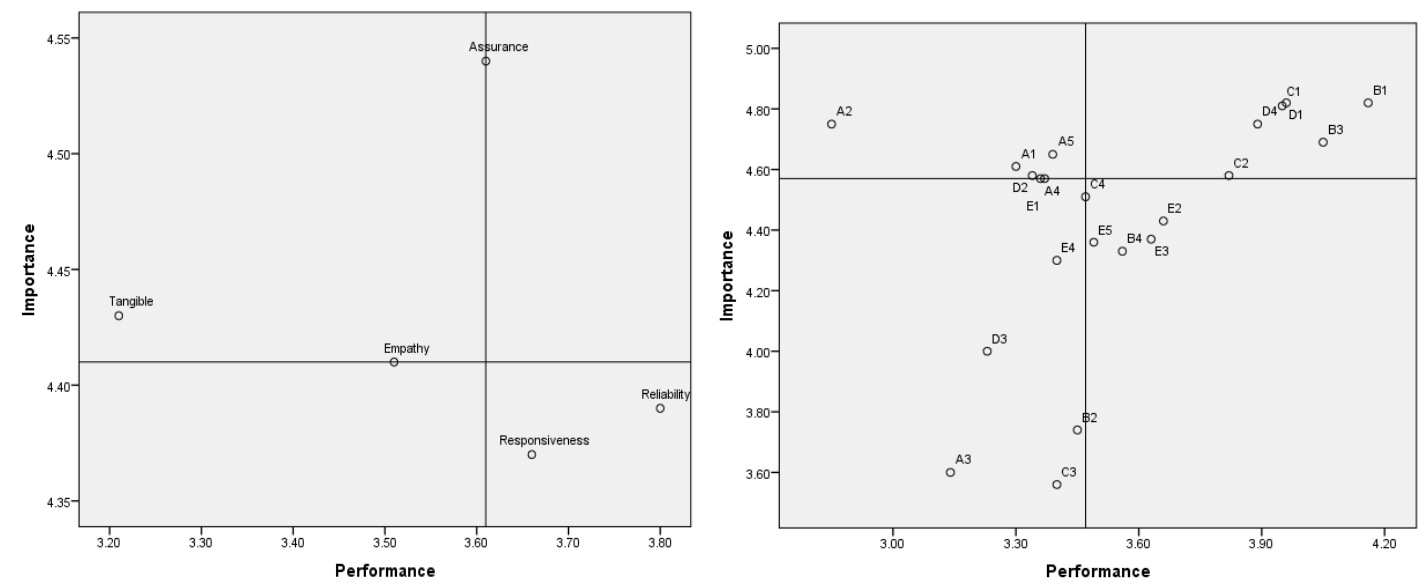

Gambar 2. Diagram IPA untuk Tiap Dimensi dan Atribut

Berdasarkan diagram IPA (Gambar 2) teridentifikasi bahwa atribut-atribut dimensi tangible umumnya berada pada kuadran pertama (menunjukkan Tingkat Kinerja Rendah namun berdasarkan preferensi responden atribut tersebut merupakan hal yang penting), dimana konsumen merasakan atribut ini sangat penting tetapi konsumen tidak puas terhadap performance layanan transportasi, atribut pada kuadran ini harus diprioritaskan untuk diperbaiki.

Untuk itu, perusahaan jasa transportasi sebaiknya harus memperhatikan kualitas layanan terutama pada dimensi tangible khsusnya pada empat kriteria yaitu kebersihan baik itu pada ruang tunggu perwakilan, toilet dan dalam bus, fasilitas yang kurang menarik, dan tidak menarik. Untuk itu harus dilakukan peningkatan kualitas krtiteria-kriteria tersebut. Selain dimensi tangible terdapat dua kriteria yang nilai kesenjangannya tinggi (diatas -1) yaitu: pelayanan yang kurang maksimal dan harga yang relatif tinggi dengan fasilitas terbatas.

\section{SIMPULAN}

Tujuan penelitian ini menekankan pada pemetaan kondisi terkini yang terkait dengan dua dimensi yang dipertimbangkan yaitu dimensi konsumen dan kualitas layanan yang dikembangkan pada tiga tujuan utama yaitu:

1. Pemetaan tingkat kualitas layanan transportasi menunjukkan bahwa secara keseluruhan responden menunjukkan ketidakpuasan terhadap seluruh dimensi hal ini terlihat dari kesenjangan antara kinerja layanan dengan harapan pelanggan yang bernilai negative. Kesenjangan yang dominan utamanya pada dimensi tangible yang terkait dengan fasilitas fisik baik pada ruang tunggu maupun fasilitas yang ada di dalam bus.

2. Berdasarkan hasil evaluasi pada diagram Importance-Performance Analysis Terdapat enam atribut yang memerlukan tindakan improvement yang sifatnya mendesak untuk dilakukan. 
Yaitu empat atribut pada dimensi tangible, satu atribut pada dimensi Assurance, dan satu atribut pada dimensi Empathy.

Penyedia jasa layanan memerlukan dukungan pendekatan dalam melakukan evaluasi kualitas layanan, salah satunya dapat mengadopsi pendekatan yang dilakukan dalam kajian ini. Pendekatan SERVQUAL dan IPA relative cukup sederhana dan efektif dalam memetakan kualitas layanan.

\section{DAFTAR PUSTAKA}

Aydemir, S. D., \& Gern, C. (2011). Measuring Serice Quality of Export Credit Agency In Turkey By Using Servqual. Procedia Social and Behavioral Sciences, 1663 - 1670.

Barabino, B., \& Deiana, E. (2013). On the attributes and influencing factors of end-users quality perceptions in urban transport: An Explotary Analysis. Procedia Social and Behavioral Sciences 87, 18 - 30.

Darmawan, A., Mulyadi, \& Fauziah. (2017). Evaluasi Kualitas Layanan terhadap Operator Telekomunikasi: Tinjauan Perspektif Pelanggan. Jurnal Optimasi Sistem Industri Vol.16 No.2, 106-111.

Erdil, S. T., \& Yildiz, O. (2011). Measuring service quality and a comparative analyss in the passenger carriage of airline industry. Procedia Behavioral Science, 1232 - 1242.

Goh, M. (Performer). (2016, October). International Seminar Research Opportunities in Supply Chain Management. Lt 1 Center of Technology, Gowa, Sulawesi Selatan, Indonesia.

Limbourg, S., Giang, H. T., \& Cools, M. (2016). Logistic Service Quality: The Case of Da Nang City. Procedia Engineering, 124-130.

Miranda, S., Ponto, I. M., \& Olmos, S. (2014). Analysis of Inclusion in the Public Transportation of People with Reduced Mobility that Live in Segregated Areas. Procedia - Social Behavioral Science, 487-495.

Pabedinskaite, A., \& Akstinaite, V. (2014). Evaluation of the airport service quality. Procedia Beavioral Science 110, 398 - 409.

Parasuraman, A., Berry, L., \& Zeithaml, V. (1991). Revinement and reassesment of the SERVQUAL scale. Journal of Retailing Vol 67 No. 4, 420 - 450.

Putra, K. E., \& Sitanggang, J. M. (2016). The Effect of Public Transport Services on Quality of Life in Medan City. Procedia Social and Behavioral Sciences, 383 - 389.

Saaty, T. L. (2008). The Analytical Hiearchy Process and Analytical Network Measurement Process: Application to Decisions under Risk. European Journal of Pure and Applied Mathematics, 122-196.

Saeed, K., \& Kurauchi, F. (2015). Enhancing the service of quality of transit systems in rural areas by flexible transport services. Transportation Research Procedia, 514 - 523. 